\title{
Analysis of efficiency of pollution reduction measures in rural basin using MIKE Basin model. Case study: Olšava River Basin
}

\author{
Jana Kaiglová, Jakub Langhammer \\ Charles University in Prague, Faculty of Science, Albertov 6, 128 43, Prague, Czech Republic. \\ ${ }^{*}$ Corresponding author. E-mail: jakub.langhammer@natur.cuni.cz
}

\begin{abstract}
This paper presents the results of testing the applicability of the MIKE Basin model for simulating the efficiency of scenarios for reducing water pollution. The model has been tested on the Olšava River Basin $\left(520 \mathrm{~km}^{2}\right)$ which is a typical rural region with a heterogeneous mix of pollution sources with variable topography and land use. The study proved that the model can be calibrated successfully using even the limited amount of data typically available in rural basins. The scenarios of pollution reduction were based on implementation and intensification of municipal wastewater treatment and conversion of arable land on fields under the risk of soil erosion to permanent grassland. The application of simulation results of these scenarios with proposed measures proved decreasing concentrations in downstream monitoring stations. Due to the practical applicability of proposed measures, these could lead to fulfilment of the water pollution limits required by the Czech and EU legislation. However, there are factors of uncertainty that are discussed that may delay or limit the effect of adopted measures in small rural basins.
\end{abstract}

Keywords: Water quality; Modelling; Rural basins; MIKE Basin; Non-point pollution; Land use.

\section{INTRODUCTION}

The rural basins represent specific and frequent problems for water management and planning due to the difficulties in identification and calculation of pollution coming from dispersed and non-point sources, a long-term perspective of change, and the frequent lack of systematic monitoring and relevant data. To evaluate information on the changes in water quality and to simulate the effect of potential measures for water pollution reduction, a number of mathematical models are available for use as versatile and easy-to-use tools for research and water management. The standard water quality models applied for the assessment of water quality in streams, e.g. QUAL2E/2K (Brown and Barnwell, 1987; Chapra et al., 2006), MIKE 11 (Havn et al., 1995) and HSPF (EPA, 2000), are usually based on a one-dimensional (1-D) conceptualization of stream hydraulics and steady-state runoff (Borah and Bera, 2003; Højberg et al., 2007; Wang et al., 2006).

The rapid development of GIS technology and the availability of detailed spatial data allowed the construction of comprehensive modelling tools for simulation of hydrological processes and contamination of the water environment, including the U.S. EPA Basins (EPA, 2001), MIKE Basin (DHI, 2008), WMS (Nelson et al., 2002) and SWAT (Arnold and Fohrer, 2005). The comprehensive models present techniques available to assess and complete the information on the pollution in space and time, and to assess the impact and efficiency of the proposed measures for abatement of the pollution (Borah and Bera, 2003).

The modelling tools require data at the level of detail that is often unavailable in typical rural catchments of small and medium size, although the solution of problems with water pollution in these basins is essential for fulfilment of objectives of water management legislation; namely the Water Framework Directive 2000/60/EC (hereinafter referred to as WfD, EC, 2000) and Nitrate Directive (EEC, 1991).

This article presents the results of research that aims at identifying the potential and limits of the MIKE Basin model for analysis and dealing with tasks related to the application of the requirements of the EU WfD (EC, 2000) in water management. The article points to the following objectives:

1. Analysis of the efficiency of point pollution reduction measures required by the current legislation in a rural basin by means of a complex model,

2. Calculation of the potential effect of measures for elimination of non-point pollution, designed with respect to their practical applicability,

3. Testing of the suitability of the MIKE Basin model for application in a small basin with limited sources of input data.

The MIKE Basin model was used for simulating the impact of measures for water quality improvement in the Olšava River Basin. This model was chosen because of its potential for solving complex issues on different basin scales (Jha and Gupta, 2003) and because of the acceptable qualitative and quantitative input data requirements. The MIKE Basin model is also being used by Czech water management authorities for modelling the impact of measures implemented in river basin management plans (RBMPs) prepared by water board authorities.

The model was applied to a case study of the Olšava River Basin, at the border between the Czech Republic and Slovakia, representing a typical rural basin with a complex structure of pollution sources and burdened with long term problems with water pollution (Langhammer and Kliment, 2009). The study evaluated the potential and limits for the application of this modelling tool in finding strategies to improve the state of water quality in the Olšava River Basin. The indicators $\mathrm{BOD}_{5}$, $\mathrm{COD}, \mathrm{N}-\mathrm{NH}_{4}, \mathrm{~N}_{-} \mathrm{NO}_{3}$ and $\mathrm{P}_{\text {total }}$ represent the basic parameters for water quality assessment and for environmental planning purposes. The simulation period is based on the same time horizon as is required in current water management legislation for setting up water management plans compliant with the EU WfD (EC, 2000). 


\section{MATERIALS AND METHODS Study area}

The Olšava River Basin is situated on the fringe of the Carpathian Range in Central Europe, at the border between the Czech Republic and Slovakia. With a size of $520 \mathrm{~km}^{2}$, the basin is typical of the rural country in a peripheral region with a diverse mixture of pollution sources and long-lasting problems with high levels of water pollution (Langhammer, 2010).

This basin is a part of the drainage basin of the Black Sea. The fan-shaped river network is made up of three main streams - Olšava, Št’ávnice (Luhačovický Creek), and Nivnička (Fig. 1). The headwaters of the Olšava River are at an altitude of 622 meters above sea level, the mouth at Kunovice, where the Olšava runs in the Morava River, is at $178 \mathrm{~m}$ a.s.l.

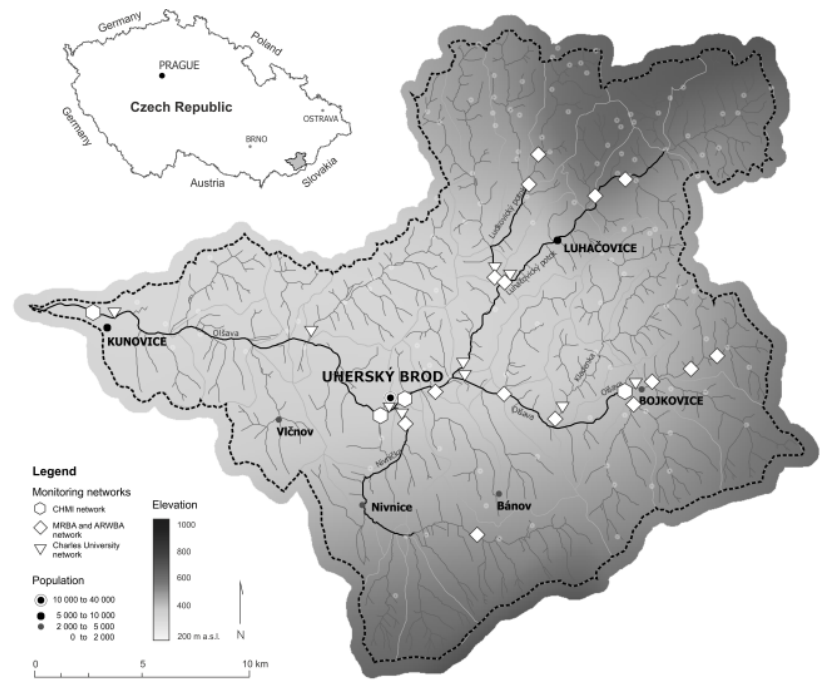

Fig. 1. Study area - Olšava River Basin, Czech Republic.

The average temperature reaches $9,1^{\circ} \mathrm{C}$ and the average precipitation rate varies from $625 \mathrm{~mm}$ in western lowlands up to $925 \mathrm{~mm}$ in highlands on the east side of the catchment. The yearly mean runoff at the catchment mouth profile is $2.5 \mathrm{~m}^{3} . \mathrm{s}^{-1}$. The value of $Q_{100}$ is $270 \mathrm{~m}^{3} \cdot \mathrm{s}^{-1}$ and during low flow period the runoff can drop below $0.5 \mathrm{~m}^{3} \cdot \mathrm{s}^{-1}$.

The land use of the basin displays a mixture of categories where forests and intense agriculture are predominant (Fig. 2). The forested areas (39.4\%) cover the headwater regions and are protected as MAB UNESCO Biosphere Reserve White Carpathians. The share of permanent grassland (4\%) has considerably increased since 1990, particularly because of the foundation of the biosphere reserve. The population of 50,300 inhabitants is concentrated in the lowland part of the river basin in the vicinity of Uherský Brod (17,500 inhabitants) and the Luhačovice Spa Resort (5,600 inhabitants). The arable land is spread over $43.3 \%$, and together with the other agricultural categories of land use, represents $54 \%$ of the basin area.

Due to the Flysh bedrock, variable topography and unsuitable location of arable land, the agricultural land in the Olšava River Basin is at a high level of erosion risk (Damaška and Jurča, 1995; Langhammer and Kliment, 2009). More than 50\% of the arable land is located on slopes with a gradient above $5^{\circ}$, and more than $20 \%$ of the arable land is located on slopes with a gradient above $8^{\circ}$. The erosion risk is evenly spread over the basin, even in the headwater regions where the precipitation totals and intensity are highest (Kliment et al., 2007).
More than $65 \%$ of the municipalities have a population lower than 1000 inhabitants. Only $37.6 \%$ of the population is connected to the integrated system of wastewater treatment (Table $1)$.

Table 1. Population integrated into a system of water treatment in the catchment of Olšava River. Data: IPR, 2010

\begin{tabular}{|c|c|c|c|c|c|}
\hline $\begin{array}{l}\text { Category of } \\
\text { municipalities }\end{array}$ & Count & $\begin{array}{c}\text { Average } \\
\text { population }\end{array}$ & $\begin{array}{l}\text { Proportional } \\
\text { rate of the } \\
\text { category on } \\
\text { total } \\
\text { population } \\
\text { of the } \\
\text { catchment } \\
(\%)\end{array}$ & $\begin{array}{l}\text { Share of } \\
\text { population } \\
\text { connected } \\
\text { to sewer- } \\
\text { age system } \\
(\%)\end{array}$ & $\begin{array}{c}\text { Share of } \\
\text { population } \\
\text { connected } \\
\text { to } \\
\text { wastewater } \\
\text { treatment } \\
\text { plant }(\%)\end{array}$ \\
\hline$<1,000$ inh. & 41 & 583 & 20.4 & 64.9 & 18.9 \\
\hline $1,000-1,999$ inh. & 11 & 1233 & 11.6 & 65.1 & 65.5 \\
\hline $2,000-4,999$ inh. & 7 & 3613 & 21.6 & 85.0 & 85.8 \\
\hline $5000>$ inh. & 4 & 13590 & 12.0 & 86.0 & 77.0 \\
\hline Total & 63 & 117098 & 100.0 & 69.0 & 37.6 \\
\hline
\end{tabular}

In the Olšava River Basin, 49 direct-point sources of pollution are recorded in the Integrated Pollution Register (IPR, 2010). These point sources consist mostly of the municipal source, but there are also several significant local industrial sources, producing emissions of high concentration of organic pollution. The direct pollution sources from agriculture are comprised of livestock, pork, and poultry breeding.

Because of its peripheral geographical position, the region remains underdeveloped, regardless of the economic development of the Czech Republic after the fall of the Communist regime in 1989 and accession to the EU in 2004. This lack of development results in limited coverage of wastewater treatment and a lack of modern sewage treatment technologies.

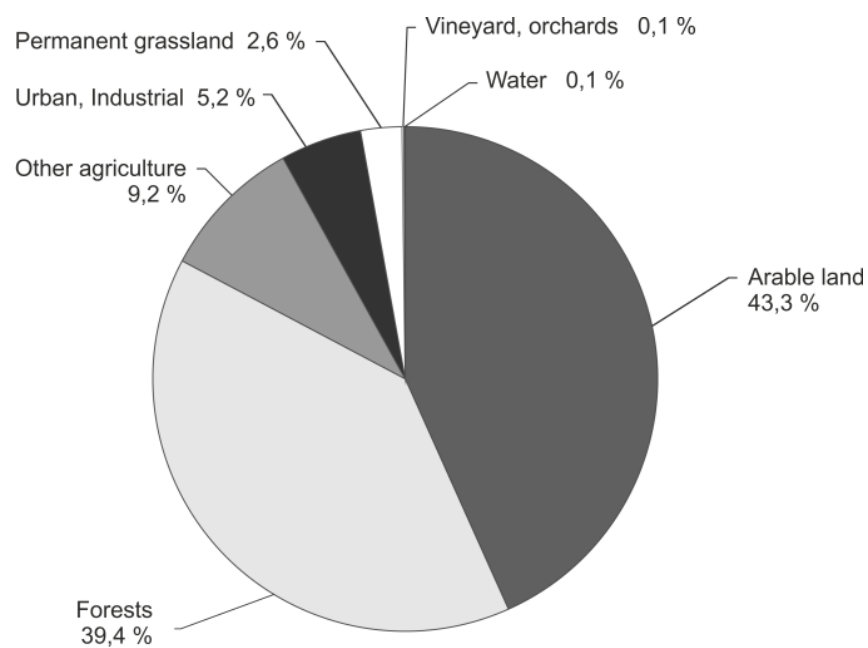

Fig. 2. Share of key land use categories in the Olšava River Basin. Data: CORINE land cover, 2000.

\section{MIKE Basin model}

The MIKE Basin (DHI, 2008) is a conceptual model that is fully integrated into the ArcGIS environment. The simulation runs on a whole catchment scale to include all the important pollution sources and pathways of contamination transport, such as surface and subsurface water uses, land use, and water structures. 
The model is built up as a conceptual river network with water user connection nodes. The catchment is divided into subcatchments belonging to the specific river reaches that are the subjects of water quality modelling. Pollution sources enter the model as a function of water users or in the form of a specific load runoff at the sub-catchment outflow. The specific load runoff can be calculated manually or with a Load Calculator tool.

The water quality module of the model simulates reactive steady-state transport of the most frequent water quality indicators - dissolved oxygen, $\mathrm{BOD}_{5}, \mathrm{COD}, \mathrm{N}-\mathrm{NH}_{4}, \mathrm{~N}-\mathrm{NO}_{3}, \mathrm{P}_{\text {total }}$, E. coli, and one user-specified conservative substance.

The degradation processes for all substances, expressed using reactive transformations (e.g. ammonia/nitrate, $\mathrm{DO} / \mathrm{BOD}_{5}$ ), are described by first-order decay rates. The steady-state qualitative and quantitative balance is calculated in time steps specified by the user, according to the project properties and task specifications.

The MIKE Basin model uses the ArGIS environment to provide pre-processing for data inputs and post-processing visualization and spatial analysis of model results.

\section{Model setup and parameterization}

For the purpose of modelling in the MIKE Basin model, the Olšava River Basin has been conceptualized into 38 subcatchments, drained into individual nodes, corresponding to individual river reaches (Fig. 3).

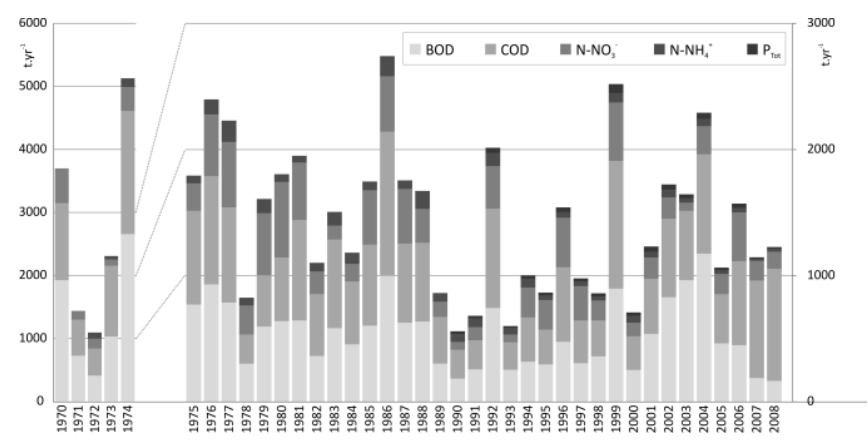

Fig. 3. Change of water pollution in selected water quality indicators in the closing profile of the basin - Olšava at Kunovice, since 1970. The missing values are caused by the later initiation of monitoring. Data: CHMI.

While the model requires quite a wide set of input parameters for the correct run of the model, the input parameters were derived from various data sources. The information on river network morphometry and basic hydraulic properties of streams was derived from the DIBAVOD geodatabase (WRI, 2010) and digital elevation model with 10-meter grid resolution, using the ArcGIS pre-processing tools.

The direct pollution sources, which were represented in the model as water users, consisted of a set of 46 entities. For each water user, there was a complete set of information on discharge and concentrations of selected pollution indicators $\mathrm{DO}, \mathrm{BOD}_{5}, \mathrm{COD}, \mathrm{N}-\mathrm{NH}_{4}, \mathrm{~N}-\mathrm{NO}_{3}$ and $\mathrm{P}_{\text {total }}$ in the yearly average concentration. Additionally, some water users provided more information. The most important water users in the basin are the municipal wastewater treatment facilities, treating the wastewater both from municipalities and local industry, where the required data are available (IPR 2010).

In available data sources, there are almost no records on pollution discharges and concentrations from small and dispersedpoint sources such as individual farms or individual houses.
These small direct sources were added to the group of nonpoint sources. As basic input data, the MIKE Basin set-up further requires monthly values of concentrations, decay coefficients, and the retention time for each stream segment.

The parameters and coefficients for simulation of non-point sources were based on values of specific load balance for subcatchments that had been calculated. The values from the observed catchments were extrapolated to the unobserved subcatchments based on the assumption that the processes driving the material transport are homogeneous in the basin. Degradation rates of non-point pollution sources were iteratively optimized during the calibration process and are based on the concept of distance-dependent decay of pollutants. Values of loads per capita were based on assumption of Ritter and Shirmohammadi, 2000; and Synáčková, 1996.

The general time step for simulation was set to one month. All data available on different time scales were processed accordingly. The balanced model aims to represent values that are characteristic for each month of a year. In order to eliminate random extreme values, the characteristic values were calculated according to the methodology of Nesměrák 2009; Tachecí, 2009. To eliminate extreme or outlier values, the concentrations are considered as a function of discharge. Based on observed data, the logarithmic function is applied for low-flow conditions and the linear function for normal flow conditions. For every monitoring profile, each set of functions was calculated based on the whole time period of evaluated measurements (2000-2007). The observed concentration values thus were replaced according to the logarithmic regression curve for low flows and a linear regression curve for discharges $[\mathrm{Q} \epsilon<\mathrm{QMmin}$, QMmax $>$ ], where QM represents the average monthly discharge during the observed period (2000-2007). The regression was calculated as a relative seasonal distribution of discharges during the whole observed period for every monitoring profile. The monthly characteristic value of discharge was calculated as an average of all daily values in individual months during the whole period 2000-2007. Values of concentration were extracted from the individual logarithmic or linear functions.

The temperature correction for all parameters was performed as a part of the MIKE Basin simulation using the empirical coefficient RateCorr.

$$
R(T)=R_{20} \cdot \text { RateCorr }^{(T-20 C)},
$$

where $R(T)$ represents the factor for actual temperature $\mathrm{T}\left({ }^{\circ} \mathrm{C}\right)$, $R_{20}$ is the degradation coefficient at the temperature $20^{\circ} \mathrm{C}$ and RateCorr is a constant set by the user.

This coefficient was set at the default as 1.07 and considered as a calibration parameter.

The self-purification process is described by a degradation coefficient $\left(\mathrm{k}_{\mathrm{x}}\right)$, length of a river reach $(\mathrm{L})$, and a residence time $\left(T_{d}\right)$. Parameters $L$ and $T_{d}$ were easily estimated from the GIS and the field survey. The coefficient of mass degradation $\left(\mathrm{k}_{\mathrm{x}}\right)$ had to be calculated for every substance and every group of reaches included in an upper catchment of individual water quality profiles. For the issues of water resources management planning, the calculation of degradation rate is represented by the simple first-order decay equation (DHI, 2008) (2):

$\frac{d X}{d_{T_{d}}}=-k_{x} \cdot X$

where $X$ represents a mass concentration and $T_{d}$ represents the residence time. This simplification includes the assumption that 
individual substances are not reciprocally involved. In the case of parameter $\mathrm{N}^{-\mathrm{NO}_{3}}$, there is a need to apply an enhanced degradation rule (DHI, 2008) (3) to describe the nitrification process as:

$\frac{d N O_{3}}{d t}=K_{N_{4}} \cdot N_{4}-K_{N O_{3}} \cdot N_{3}$,

where $K_{\mathrm{NH}_{4}}$ represents the nitrification coefficient at $20^{\circ} \mathrm{C}$ [1/day], $\mathrm{K}_{\mathrm{NO}_{3}}$ is the denitrification coefficient at $20^{\circ} \mathrm{C}[1 /$ day] and $\mathrm{NO}_{3}$ and $\mathrm{NH}_{4}$ refer to the amount of nitrogenous substances. Although $\mathrm{N}-\mathrm{NO}_{3}$ concentration may be predominantly produced by the nitrification of $\mathrm{N}-\mathrm{NH}_{4}$, other sources of $\mathrm{N}-\mathrm{NO}_{3}$, such as the agricultural sources of non-point pollution, are also significant.

The calculation of a degradation coefficient was based on empirical studies done for the Czech environment (Behrendt et al., 1995).

The MIKE Basin Water Quality module is unable to reflect the yearly variability in the degradation coefficients because the coefficients remain constant for the whole model run. The decay coefficients were thus applied as average values derived from the supplementary data sources (Table 2). Values were calculated according Nesměrák, 2009 (4).

$\mathrm{K}_{\mathrm{x}}=\log \left(\frac{1}{\mathrm{PRA}_{\mathrm{PS}}}\right), \quad$ where $\mathrm{PZS}_{\mathrm{BZ}}=10^{\mathrm{a} / \mathrm{Q}}$

where $\mathrm{K}_{\mathrm{x}}$ is a degradation coefficient, $\mathrm{PRA}_{\mathrm{PS}}$ represents a procentual residue of point sources after the self-purification process during the low flow period, a is a nonlinear coefficient of the logarithmic function found for each monitoring site, and Q represents the discharge of a characteristic month. From the resulting monthly characteristic coefficients, the average value was calculated and used for the water quality model set-up.

The Load Calculator tool was used to calculate the input data for modeling the impact of non-point sources on water quality in the basin. The calculation is based on a principle of typical concentrations, related to the respective number of inhabitants, livestock, and arable land, and is spatially expressed as shape file. The result is calculated in the form of a time series of specific loads that are used as further input to the model. The applied coefficients were derived from observed and reported values from the basin and calculated values of specific loads (Ritter and Shirmohammadi, 2010, Synáčková 1996). The input data is publically available from municipal and state statistical sources (CSO, 2012). The hydraulic retention time was derived for each river reach from a combination of GIS data and field observation (5).

$\operatorname{Tr}=\frac{\mathrm{v}_{\mathrm{a}}}{\mathrm{L}}$,

where $\operatorname{Tr}$ represents the hydraulic retention time, $\mathrm{v}_{\mathrm{a}}$ is the flow velocity in the given reach, and $\mathrm{L}$ is the river reach length.

The value of the river reach length $\mathrm{L}$ was calculated from the DIBAVOD geodatabase (WRI, 2010). The mean flow velocity $\mathrm{v}_{\mathrm{a}}$ was derived from the results of repeated hydrometric measurements at 10 monitoring stations in the monitoring network maintained by Charles University in Prague (Langhammer and Kliment, 2009), and periodically repeated since 2001. The measured velocity values were related to the respective discharge values, and the derived function was used for characteristic monthly velocities based on calculated characteristic monthly discharge values.

\section{Model calibration and validation}

The model was calibrated to obtain the highest possible agreement between the simulated and observed values using the Nash-Sutcliff model efficiency coefficient (6).

$E_{f}=1-\frac{\sum_{i}^{n}\left(Y_{o i}-Y_{m i}\right)^{2}}{\sum_{i}^{n}\left(Y_{m i}-\bar{Y}_{m}\right)^{2}}$,

where $\mathrm{Y}_{\mathrm{oi}}$ represents observed values and $\mathrm{Y}_{\mathrm{mi}}$ are modeled values (Nash and Sutcliff, 1970).

The water quality model calibration was based on comparing the average monthly values of concentrations of water quality indicators and discharge values for monitoring profiles in the basin with simulated values. Main calibration parameters were decay constants $\mathrm{k}_{\mathrm{t}}$ and the temperature coefficient RateCorr.

For the calibration of the coefficient of change of concentration of non-point pollution in the Load Calculator module, the sub-catchments of Nivnička were selected, as they intersect with the village of Nivnice. Nivnice produces livestock which graze on the land. The validation of calibrated parameters was performed on the sub-catchment ZPPOv009, where the cooperative of Nezdenice is located.

The decay coefficients were compared to keep the homogeneity in the areas with similar physiographic features. For stream segments with reservoirs, the retention times were prolonged up to $100 \mathrm{hrs}$. to correctly describe the effect of the reservoir on the stream water quality.

After the calibration, the model was validated with the dataset from 2006. The continuous simulation revealed varying effects of point and non-point pollution sources and distribution of pollution levels across the basin in the year.

The best conditions in terms of water quality are detected in the winter because of the lower average precipitation and runoff values as well as limited discharge at most of the point pollution sources.

During the spring, elevated values of load from non-point sources are evident. The high load from non-point pollution sources and from inter-basins is recorded in the upper parts of all major tributaries of the basin.

Summer represents the most critical period of the year in terms of water pollution. The low discharge, high water temperature and high levels of wastewater discharges from point sources are the reasons for the critical concentrations of organic pollutants, especially in the municipal sources. Since September, the levels of water pollution both at headwaters and lower parts of the basin decrease because of the higher average runoff, lower temperatures and lower volumes of wastewater discharges.

Although the basin is located in a typical rural area, the presence of relatively important municipal and industrial (food industry, machinery) point sources makes its water quality regime more complex. The resulting variability of pollution is thus driven by a mixture of factors, including physiography, agricultural activity, and municipal and industrial wastewater discharges.

The critical stream segments in terms of water pollution can be identified, especially in the central part of the basin, as consequence of emissions from important point pollution sources, either from municipal wastewater or livestock production (Fig. 5). Fig. 5 shows the current state of water quality in individual reaches of the main streams of the Olšava River Basin. Concentrations of all evaluated substances were put into one figure as the resulting water quality class is, according to the Czech water quality classification standard CSN 757221 based on the worst-evaluated parameter. 
Table 2. Parameters necessary for the MIKE Basin simulation and calibration and corresponding characteristic values.

\begin{tabular}{|c|c|c|c|c|c|c|}
\hline Parameter & Units & Description & Data Source & Average & Min & Max \\
\hline $\mathrm{T}_{\mathrm{d}}$ & hour & Reach residence time & $\begin{array}{l}\text { CUNI, MRBA, AWMA, } \\
\text { CHMI }\end{array}$ & 32.79 & 0.21 & 414.47 \\
\hline $\mathrm{k}_{\mathrm{d}}$ & - & Coefficient of mass degradation & $\begin{array}{l}\text { CHMI, MRBA, AWMA, } \\
\text { IPR }\end{array}$ & 0.11 & 0.01 & 0.30 \\
\hline $\mathrm{L}$ & $\mathrm{Km}$ & Reach length & WRI & 1.86 & 0.11 & 13.22 \\
\hline $\mathrm{F}$ & $\mathrm{km}^{2}$ & Area of sub catchment & WRI, MIKE Basin & 14.46 & 0.58 & 50.90 \\
\hline $\mathrm{v}_{\mathrm{st}}$ & $\mathrm{m} / \mathrm{s}$ & Mean flow velocity & $\begin{array}{l}\text { CHMI, MRBA, AWMA, } \\
\text { IPR }\end{array}$ & 0.84 & 0.02 & 5.76 \\
\hline $\mathrm{T}$ & ${ }^{\circ} \mathrm{C}$ & $\begin{array}{l}\text { Monthly characteristic water } \\
\text { temperature }\end{array}$ & CHMI & 10.53 & 0.38 & 21.74 \\
\hline QWaterUser & $\mathrm{m}^{3} / \mathrm{s}$ & $\begin{array}{l}\text { Discharge of extraction or emis- } \\
\text { sion of water by water user }\end{array}$ & IPR & 0.04 & 0.00 & 250.00 \\
\hline $\mathrm{c}_{\text {WaterUser }}$ & $\mathrm{mg} / \mathrm{l}$ & $\begin{array}{l}\text { Characteristic concentration of } \\
\text { emitted water }\left(\mathrm{BOD}_{5}, \mathrm{COD}, \mathrm{N}-\right. \\
\left.\mathrm{NH}_{4}, \mathrm{~N}-\mathrm{NO}_{3}, \mathrm{P}_{\text {total }}\right)\end{array}$ & IPR & 49.52 & 0.08 & 500.00 \\
\hline Q & $1 / \mathrm{s} / \mathrm{km}^{2}$ & $\begin{array}{l}\text { Specific runoff from sub catch- } \\
\text { ment area }\end{array}$ & Calculation & 0.21 & 0.03 & 1.16 \\
\hline $\mathrm{LO}_{\mathrm{NPS}}$ & $\mathrm{g} / \mathrm{s}$ & $\begin{array}{l}\text { Specific mass transport from sub } \\
\text { catchment area }\left(\mathrm{BOD}_{5}, \mathrm{COD}, \mathrm{N}-\right. \\
\left.\mathrm{NH}_{4}, \mathrm{~N}-\mathrm{NO}_{3}, \mathrm{P}_{\text {total }}\right)\end{array}$ & Calculation & 0.04 & 0.00 & 0.22 \\
\hline $\mathrm{c}_{\mathrm{char}} \mathrm{BOD}_{5}$ & $\mathrm{mg} / \mathrm{l}$ & $\begin{array}{l}\text { Monthly characteristic concentra- } \\
\text { tions according to the biological } \\
\text { oxygen demand in } 5 \text { days }\end{array}$ & CHMI, MRBA, AWMA & 1.45 & 0.16 & 5.26 \\
\hline $\mathrm{c}_{\mathrm{char}} \mathrm{COD}$ & $\mathrm{mg} / \mathrm{l}$ & $\begin{array}{l}\text { Monthly characteristic concentra- } \\
\text { tions according to the chemical } \\
\text { oxygen demand }\end{array}$ & CHMI, MRBA, AWMA & 7.41 & 0.68 & 17.84 \\
\hline $\mathrm{c}_{\text {char }} \mathrm{N}-\mathrm{NO}_{3}$ & $\mathrm{mg} / \mathrm{l}$ & $\begin{array}{l}\text { Monthly characteristic concentra- } \\
\text { tions of nitrate }\end{array}$ & CHMI, MRBA, AWMA & 1.05 & 0.02 & 3.15 \\
\hline $\mathrm{c}_{\text {char }} \mathrm{N}-\mathrm{NH}_{4}$ & $\mathrm{mg} / \mathrm{l}$ & $\begin{array}{l}\text { Monthly characteristic concentra- } \\
\text { tions of ammonia }\end{array}$ & CHMI, MRBA, AWMA & 0.11 & 0.01 & 0.65 \\
\hline $\mathrm{c}_{\text {char }} \mathrm{P}_{\text {total }}$ & $\mathrm{mg} / \mathrm{l}$ & $\begin{array}{l}\text { Monthly characteristic concentra- } \\
\text { tions of total phosphorus }\end{array}$ & CHMI, MRBA, AWMA & 0.11 & 0.01 & 0.48 \\
\hline Q & $\mathrm{m}^{3} / \mathrm{s}$ & Monthly characteristic Discharge & CHMI & 0.86 & 0.02 & 7.27 \\
\hline
\end{tabular}

Abbreviations: CUNI (Charles University in Prague, Faculty of Science); MRBA (Morava River Basin Authority); AWMA (Agricultural Water Management Authority); CHMI (Czech Hydro-Meteorological institute); IPR (Integrated Pollution Register); WRI (Water Research Institute Prague).

\section{Model scenarios}

To decrease the level of water pollution in the Olšava River Basin, proposed scenarios were based on different types of measures. The measures were designed to fulfil the following criteria:

compliance with the Czech and EU water management legislation,

- compliance with the Water Management plans issued by the River Basin Authorities and

- practical applicability.

Two groups of measures that focused on point and non-point sources were considered.

The measures proposed for decrease of load from direct pollution sources have been focused on improvement of efficiency of wastewater treatment, mainly at the municipal sources that primarily contribute to the overall pollution balance. These measures are required by the $\mathrm{EU} \mathrm{WfD}$ (EC, 2000), and are implemented in the long-term plans of River Basin Authorities.

First, wastewater treatment facilities were proposed for communities currently not equipped with a wastewater treatment facility, according to the WfD requirements applied to communities with 2,000 inhabitants or more. In the second step, tertiary wastewater treatment technology was applied, as required by the $\mathrm{WfD}$, for cities with 10,000 inhabitants or more. The WfD also requires the tertiary treatment in communities with 5,000 inhabitants or more, when they are located in vulnerable areas.

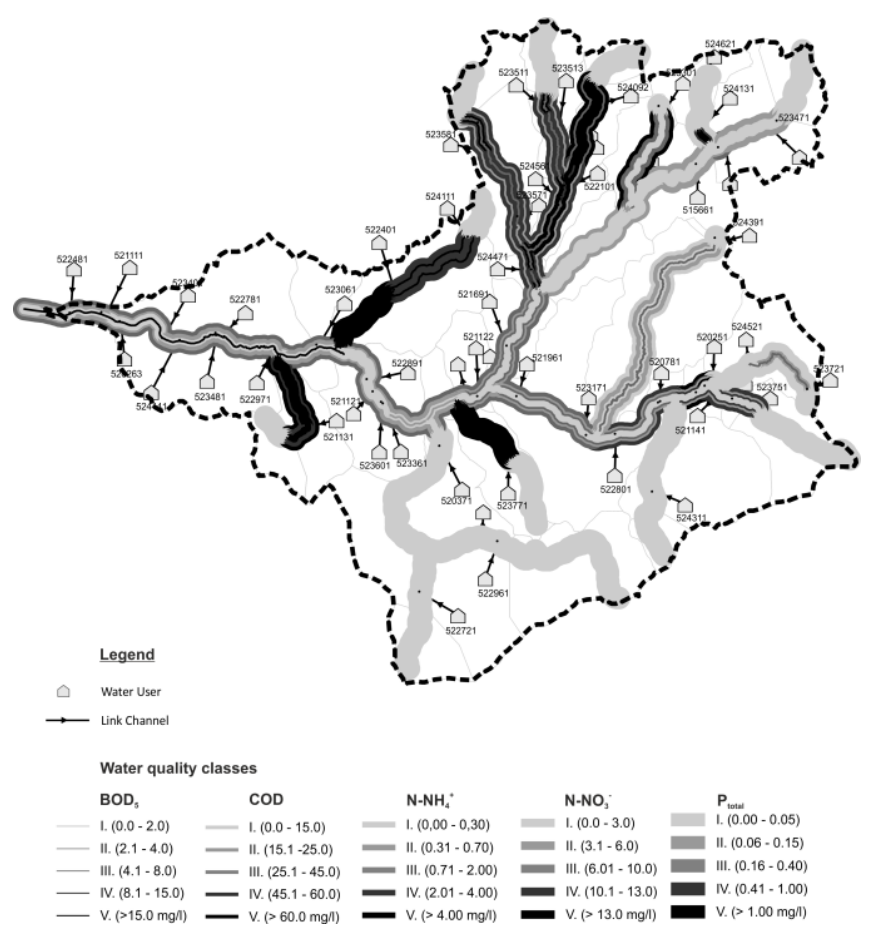

Fig. 5. Yearly average values of the model of the current state of the Olšava River Basin water quality.

The measures aimed to diminish the pollution loads from non-point sources were mainly focused on the changes in land use and land cover. The most critical land cover types were 
identified as fields with arable land located on steep slopes with an inclination over $12^{\circ}$ directly connected to a recipient. These areas were proposed for being transferred into the permanent grassland category. The experience of conversion of arable land into pastures in other regions proved that this form of activity can be economically beneficial (Withers, 2007), so the proposed change was considered as being potentially acceptable to the stakeholders.

In the MIKE Basin model, the scenarios for point pollution sources have been set up as a modification of the original time series and datasets. For the non-point pollution sources, the measurements were applied using the MIKE Basin Load Calculator. This tool is based on the spatial analysis of ArcGIS layers that contain information about the amount of fertilizer applied, count of livestock, and industrial and domestic sources. The value of concentration is added to the amount of pollution. The last step is to specify the value of decay within the drainage path towards the recipient. Those values were first estimated according the distance from the recipient and later calibrated and compared with values reported in relevant literature (Rosendorf and Prchalová, 1999).

\section{Data Sources}

The model is based on different sets of data supplied by various providers. The water quality data used for analysis of the current state and development of surface water pollution in the basin were supplied by the authorities providing monitoring in the region: the Czech Hydrometeorological Institute (CHMI), Morava River Basin Authority (MRBA), and Agricultural Water Board Authority (AWBA). These data were completed by the results from the network of monitoring secured by Charles University in Prague at 10 monitoring sites.

Water quality indicators were selected to be relevant to the parameters simulated by the MIKE Basin model and included $\mathrm{DO}, \mathrm{BOD}_{5}, \mathrm{COD}, \mathrm{N}-\mathrm{NH}_{4}, \mathrm{~N}-\mathrm{NO}_{3}$, and $\mathrm{P}_{\text {total. }}$. The assessment of long-term trends of water quality at the river mouth profile uses data from 1970-2010. The monitoring network covering the inner river network of the basin consists of 19 stations monitoring water quality and 8 stations for the monitoring of discharge. This interval was defined to prove the representativeness of individual datasets by including both dry $\left(2003, Q=1.14 \mathrm{~m}^{3} \cdot \mathrm{s}^{-1}\right)$ and wet $\left(2000, Q_{\text {year }}=4.3 \mathrm{~m}^{3} \cdot \mathrm{s}^{-1}\right)$ years.

The Integrated Pollution Register (IPR, 2010) database was used as a source of information on emissions of direct pollution. The DIBAVOD geodatabase (WRI, 2010) was used as a reference digital map resource, which was completed by the CORINE land cover (EEA, 2009) database and general topographic layers.

All acquired data were statistically processed to eliminate the gaps in time series. The missing values were filled by correlation with the most suitable and accurate time series.

\section{RESULTS}

\section{Water quality changes in the Olšava River Basin}

The Olšava River Basin has experienced intense water pollution over the last few decades with pollution occurring even in the small streams in the mountains.

The water quality is a long-term problem for water management of the basin. Extreme levels of pollution in key indicators, which were reached in the 1970 s, decreased and there is an apparent positive shift in most indicators; however, the water quality in the basin since the late 1980s has improved only slightly and there are repeated peaks of pollution (Fig. 4). Pol- lution in $\mathrm{BOD}_{5}$, ammonium nitrate or total phosphorus, displayed only limited change since the 1990s with repeated peaks of pollution. The decrease of concentrations in indicators reflecting industrial pollution $\left(\mathrm{COD}, \mathrm{N}_{-} \mathrm{NH}_{4}^{+}\right)$is linked to the efficiency of treatment in the major wastewater treatment facilities and to the decline of economic activities.

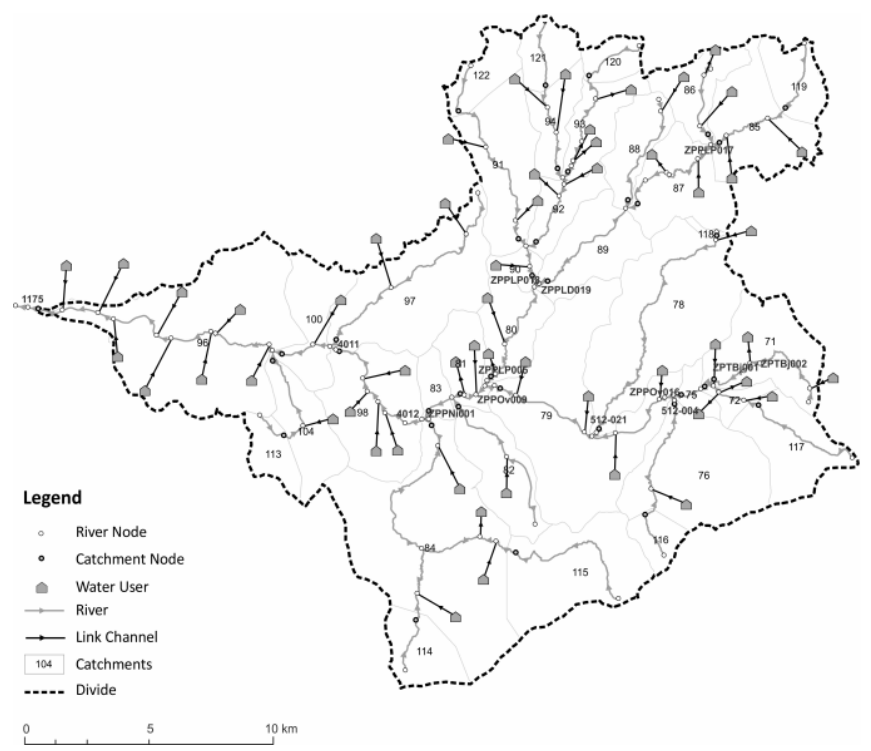

Fig. 4. Conceptualization of river network and sub-catchment structure in the MIKE Basin model for the Olšava River Basin.

The low average discharge of recipients is not adequate to the spatially-concentrated emissions from municipal and local industrial pollution and makes the ecosystem vulnerable. This vulnerability can be documented by the extreme peak of pollution caused by water treatment failures after the floods in 2006 which resulted in unprecedented concentrations of organic pollutants compared to the last 20 years.

The contamination of surface waters by toxic waste from local industry, mainly by heavy metals $(\mathrm{Cd}, \mathrm{Hg})$, was eliminated during the 1990s. However, the decrease of elevated concentrations of pollutants was not due to these systematic measures, but occurred as a result of the economic collapse of the former industrial activities during the transformation era of the Czech economy in the 1990s. The Olšava River Basin did not follow the trend of quick depollution that occurred in large streams in the Czech Republic since major political changes in 1990 when the decline of economic activities went in conjunction with investments in wastewater treatment, which led to substantial and lasting improvements in water quality in large rivers (Langhammer, 2010).

Regardless of the apparent slow decrease in pollution, the remaining levels of concentrations in most indicators can be regarded as high in respect to the basin characteristics. The actual pollution levels are comparable to the concentrations observed for large rivers in industrial and urbanized areas. This montane basin, which is located in an underdeveloped region with scarce settlement and an extensive headwater area, is protected as a biosphere reserve. It has the potential for a much lower level of pollution, particularly in the upper and central parts of the basin. 


\section{SIMULATION OF SCENARIOS OF POLLUTION DE- CREASE}

\section{Effect of point pollution decrease}

The scenario was based on the simple application of a basic level of wastewater treatment for communities with more than 1,000 inhabitants and the application of tertiary wastewater treatment for communities above 5,000 inhabitants in vulnerable zones, delimited according to the Nitrate Directive 91/676 EC. These measures were applied for the real numbers of inhabitants currently connected to wastewater treatment facilities. For the rest of the inhabitants in these communities, there was an applied wastewater treatment efficiency of $87 \%$ in $\mathrm{BOD}_{5}$ and $81 \%$ in COD.

The results indicate a significant increase in water quality, especially in the ammonia nitrogen $(7.9 \%)$ and $\mathrm{BOD}_{5}(5.1 \%)$ parameters (Table 3). The highest effect of the measure is shown on lower reaches of the Olšava River under Uherský Brod (Fig. 6), where the application of a more strict wastewater treatment standard would shift the water pollution level from water quality class V to III, i.e., from the worst class to a midlevel class. The same improvement has been detected in small streams polluted by currently untreated municipal wastewater, including Ludkovický, Vlčnovský, and Bánovský Creek. The pollution levels of small tributaries in rural sub-catchments remain unchanged.

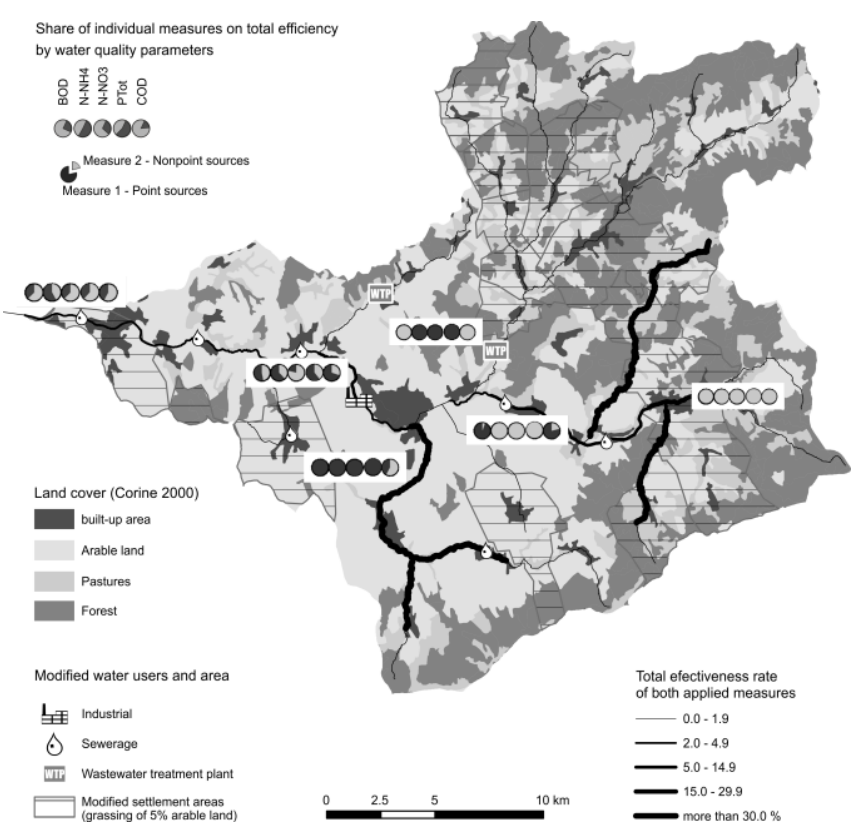

Fig. 6. Total effectiveness of two measures applied in the model of the current state of water quality in the Olšava River Basin in parameters $\mathrm{BOD}_{5}, \mathrm{~N}-\mathrm{NH}_{4}{ }^{+}, \mathrm{N}-\mathrm{NO}_{3}, \mathrm{P}_{\text {total }}$ and $\mathrm{COD}$.

\section{Effect of non-point pollution reduction}

In the sub-catchments with the most critical levels of pollution related to agriculture, this model scenario proposed converting $5 \%$ of the arable land to grassland. The share of arable land suggested for conversion was based on expert estimates of realistic scenarios applicable in the current socioeconomic conditions of the area. The main aim of land use development is to reduce erosion potential by considerate exploitation of the most exposed parts of arable land (Psotová, 2008).

Table 3. Efficiency of scenarios.

\begin{tabular}{lccc}
\hline Parameter & $\begin{array}{l}\text { Point pollution } \\
\text { reduction \% }\end{array}$ & $\begin{array}{l}\text { Nonpoint pollution } \\
\text { reduction \% }\end{array}$ & $\begin{array}{l}\text { Point }+ \\
\text { Nonpoint } \\
\%\end{array}$ \\
\hline $\mathrm{BOD}_{5}$ & 5.1 & 5.6 & 10.4 \\
$\mathrm{COD}$ & 3.9 & 3.1 & 6.6 \\
$\mathrm{NH}_{4}{ }^{+}$ & 7.9 & 7.8 & 13.8 \\
$\mathrm{NO}_{3}^{-}$ & 2.7 & 7.2 & 8.3 \\
$\mathrm{P}_{\text {total }}$ & 3.8 & 5.1 & 7.5 \\
\hline
\end{tabular}

The efficacy of this measure is highest for both forms of nitrogen: ammonia (7.8\%) and nitrates (7.2\%). The positive effect of this measure is apparent mainly in the small sub-basins in the flat central and lower parts of the basin, as well as in the upper parts of the basin where the arable land is often located in unsuitable conditions in terms of slope and erosion vulnerability.

\section{Cumulative effect of both point and non-point pollution reduction}

The scenario combining measures at point and non-point pollution sources showed the potential of the basin for reducing pollution under the current conditions. The highest efficiency was achieved in the ammonia nitrogen parameter where the reduction achieved was $13.8 \%$. The decrease of pollutant concentrations was achieved in the central part of the basin, and was particularly apparent in the northern part of the basin at Luhačovický and Ludkovický Creek. The positive effect of implementation of tertiary treatment is apparent at all major wastewater treatment facilities and the respective river reaches, namely at the cities of Luhačovice, Uherský Brod, and Kunovice (Fig. 6).

The decrease in load by organic pollution in the $\mathrm{BOD}_{5}$ indicator is apparent in the reaches under the small municipal sources without previous wastewater treatment. The decrease in load especially applies to the small effluents at the communities of Vlčnov, Bánov, or Petrůvka in the lower part of the basin. The changes in organic pollution in COD were marginal.

The proposed measures led to a decrease of concentrations of nitrates by $8.3 \%$. The concentrations of nitrates at the monitoring stations show non-declining levels during the whole period of observation. The suggested measures, especially the changes in land use structure, seem to indicate that positive results are possible. The total phosphorus concentrations declined by $7.5 \%$, again mainly due to the changes in land use. The major impact of the proposed measures is apparent in the headwater region and at small effluents in the central part of the Olšava River Basin. 
Table 4. MIKE Basin simulation results of two most effective scenarios.

\begin{tabular}{|c|c|c|c|c|c|c|c|c|c|c|c|}
\hline & & & $\begin{array}{l}\text { Measure } \\
\text { f wastew }\end{array}$ & $\begin{array}{l}\text { Enhancec } \\
\text { r tretmer }\end{array}$ & $\begin{array}{l}\text { ecien } \\
\text { ants ( }\end{array}$ & & & $\begin{array}{r}\text { Me } \\
\text { f selecte }\end{array}$ & $\begin{array}{l}\text { Ire } 2: \mathrm{Gr} \\
\text { gricultu }\end{array}$ & $\begin{array}{l}\text { ig } \\
\text { nds ( }\end{array}$ & \\
\hline \multirow{6}{*}{$\begin{array}{c}\text { Gauging } \\
\text { profile } \\
\text { Kunovice } \\
1175\end{array}$} & & $\overline{\mathrm{BOD}_{5}}$ & $\mathrm{~N}-\mathrm{NH}_{4}$ & $\mathrm{~N}-\mathrm{NO}_{3}$ & $\overline{\mathrm{P}_{\text {total }}}$ & COD & $\mathrm{BOD}_{5}$ & N-NH 4 & $\mathrm{~N}-\mathrm{NO}_{3}$ & $\overline{\mathrm{P}_{\text {total }}}$ & COD \\
\hline & SPRING & 4.7 & 9.5 & 2.9 & 3.5 & 4.4 & 7.5 & 5 & 4.6 & 6.1 & 3.6 \\
\hline & SUMMER & 6.1 & 9.5 & 3.9 & 4.2 & 3.3 & 7.3 & 7 & 6.6 & 6.6 & 7 \\
\hline & AUTUMN & 7.2 & 11.8 & 4.4 & 4.8 & 4.7 & 7.1 & 5.7 & 5.9 & 6.3 & 5.9 \\
\hline & WINTER & 3.7 & 7.6 & 2.4 & 3 & 2.8 & 7.6 & 5 & 5.2 & 6.3 & 43 \\
\hline & Average & 5.4 & 9.6 & 3.4 & 3.9 & 3.8 & 7.4 & 5.7 & 5.6 & 6.3 & 5.2 \\
\hline \multirow{5}{*}{$\begin{array}{c}\text { Middle } \\
\text { reaches of } \\
\text { Olšava river } \\
4012\end{array}$} & SPRING & 1.6 & 0 & 0.1 & 0.2 & 1.3 & 10.2 & 9.7 & 2.6 & 7.6 & 7.7 \\
\hline & SUMMER & 1.5 & 0.1 & 0.1 & 0.1 & 1.2 & 19.9 & 19.5 & 6 & 17.9 & 17.3 \\
\hline & AUTUMN & 1.9 & 0.1 & 0.2 & 0.2 & 1.6 & 15 & 14.3 & 4.8 & 12.9 & 12.4 \\
\hline & WINTER & 1.1 & 0 & 0.1 & 0.1 & 0.8 & 12.3 & 11.3 & 2.9 & 9.5 & 9.3 \\
\hline & Average & 1.5 & 0 & 0.1 & 0.2 & 1.2 & 14.3 & 13.7 & 4.1 & 12 & 11.7 \\
\hline \multirow{5}{*}{$\begin{array}{l}\text { Right side } \\
\text { tributary } \\
\text { Luhačovický } \\
\text { stream } \\
\text { ZPPLP005 }\end{array}$} & SPRING & 0 & 0.1 & 0.6 & 0.5 & 0 & 13 & 6.5 & 5.1 & 5.5 & 3.7 \\
\hline & SUMMER & 0 & 0.2 & 0.6 & 0.5 & 0 & 7.9 & 6.3 & 5.7 & 5.9 & 2.9 \\
\hline & AUTUMN & 0 & 0.6 & 0.7 & 0.7 & 0 & 8.7 & 5.9 & 5.4 & 5.8 & 3 \\
\hline & WINTER & 0 & 0.4 & 0.4 & 0.3 & 0 & 14.1 & 6 & 5.3 & 5.8 & 3.5 \\
\hline & Average & 0 & 0.3 & 0.6 & 0.5 & 0 & 10.9 & 6.2 & 5.4 & 5.8 & 3.3 \\
\hline \multirow{5}{*}{$\begin{array}{c}\text { Upper } \\
\text { reaches of } \\
\text { Olšava river } \\
\text { ZPPOv016 }\end{array}$} & SPRING & 31.9 & 0.3 & 49.3 & 18.1 & 3.9 & 2 & 0 & 30.4 & 9.5 & 4 \\
\hline & SUMMER & 19.5 & 0.1 & 42.9 & 35.4 & 8.7 & 1.6 & 0 & 26.9 & 19.4 & 3.5 \\
\hline & AUTUMN & 19.6 & 0.2 & 41.6 & 27.4 & 6.7 & 1.6 & 0 & 26.2 & 15 & 3.2 \\
\hline & WINTER & 30 & 0.4 & 52.5 & 26.9 & 4.8 & 1.9 & 0 & 32.5 & 14.5 & 3.8 \\
\hline & Average & 25.2 & 0.2 & 46.6 & 27 & 6 & 1.8 & 0 & 29 & 14.6 & 3.6 \\
\hline
\end{tabular}

The most intense positive effect of the proposed measures is apparent in the following regions (Fig. 6):

1. The lower part of the Olšava River from Uherský Brod to the mouth profile,

2. The upper part of the Olšava River up to Bojkovice,

3. The northern part of the basin at the confluence of Ludkovický and Luhačovický Creek,

4. At the left-side effluents of the Olšava River in the lower part of the Basin - Nivnička, Vlčnovský, and Bánovský Creek.

The changes in pollution load slightly affect the seasonal distribution of concentrations in the basin (Table 4). The most significant changes were detected in the indicators dependent on emissions from point pollution sources, e.g. $\mathrm{N}_{-} \mathrm{NH}_{4}$ and $\mathrm{BOD}_{5}$. The highest decrease in concentrations is apparent during summer and fall, when the maximum values of pollution load are observed. The lowering of the level of maximum pollution concentrations is highly positive, especially in view of the low discharge values in the summer period (Fig. 7) and can be regarded as a step towards decreasing the vulnerability of the river ecosystem.

\section{Pollution load structure}

The portions of non-point pollution on the total pollution balance are related to the rural character of the basin. In the upper parts of the basin, the non-point pollution in nutrients reaches $61-74 \%$. In the lower parts, the share of non-point pollution is between $41-63 \%$. Shares were derived from the model of the current state of the Olšava River Basin. All pollution sources that were not considered as point sources were automatically evaluated as non-point sources. The resulting high percentages of non-point pollution in nutrients on the overall balance have been compared to other studies.

However, these percentages are affected by incomplete information on discharge from local municipal point sources, which are unlisted in the integrated pollution register. These results are in line with the findings reported by different authors (Beránková et al., 2010; Langhammer, 2004). The high shares of non-point pollution, especially in nutrients, are common in rural basins. However, the case studies from different environments (Maillard and Santos, 2008; Salvetti et al., 2008; Wang et al., 2006) show that regardless of the similarities in land use, the non-point pollution sources can vary significantly, mainly due to different physiography (geology, lithology, soil conditions, land cover and others), climate conditions, and variations in load from local point pollution sources.

\section{DISCUSSION}

The mathematical models of a river network, and especially the models of water quality, are burdened by high levels of simplification due to the complexity of processes described and their conceptualization in the model (Beven, 2000). The generalization affects all aspects and phases of the model construction and use. However, there are several common shortcomings. The conceptualization of streams as 1-D hydraulic structures results in an incorrect representation of the flow, mainly on larger riverbeds; in addition, this representation is considered as homogenous in the horizontal and vertical aspects (Shanahan et al., 1998). The organic pollution indicators $\mathrm{BOD}_{5}$ and COD are treated as individual substances that degrade over time, even when they are aggregate parameters of the redox processes in the stream. The processes affecting the variability and seasonality of the load from the point and non-point sources are substantially different and should be treated separately (Marsili-Libelli and Giusti, 2008; Pekarova et al., 2004). The calibration process and application of autocalibration tools can result in the application of parameter values that are far from the real conditions, and thus even the well-calibrated model can lead to misinterpretation and unexpected results (Paliwal et al., 2007).

The appropriate modelling tool, thus, has to be able to generalize the processes of water pollution transport and degradation at a level that allows the use of limited data inputs with adequate accuracy in results and in the robustness of the model. The comprehensive models including SWAT, HSPF, or MIKE Basins have some known general shortcomings resulting from the conceptualization of physical processes. The inaccuracies are reported in the generation of runoff and related material transport (Buchanan et al., 2011; Easton et al., 2008). The prevailing approach, based on the SCS curve number equation, 
distributes the runoff and related pollutant loads in larger areas that correspond to the critical contributing areas that are highly differentiated in space (Beven, 2000). The concept of variable source areas, applied, e.g. in the SWAT-VSA model (Easton et al., 2008), seems to be able to improve the accuracy of results, mainly for storm runoff. However, such approaches are demanding for data and parameter calibration.
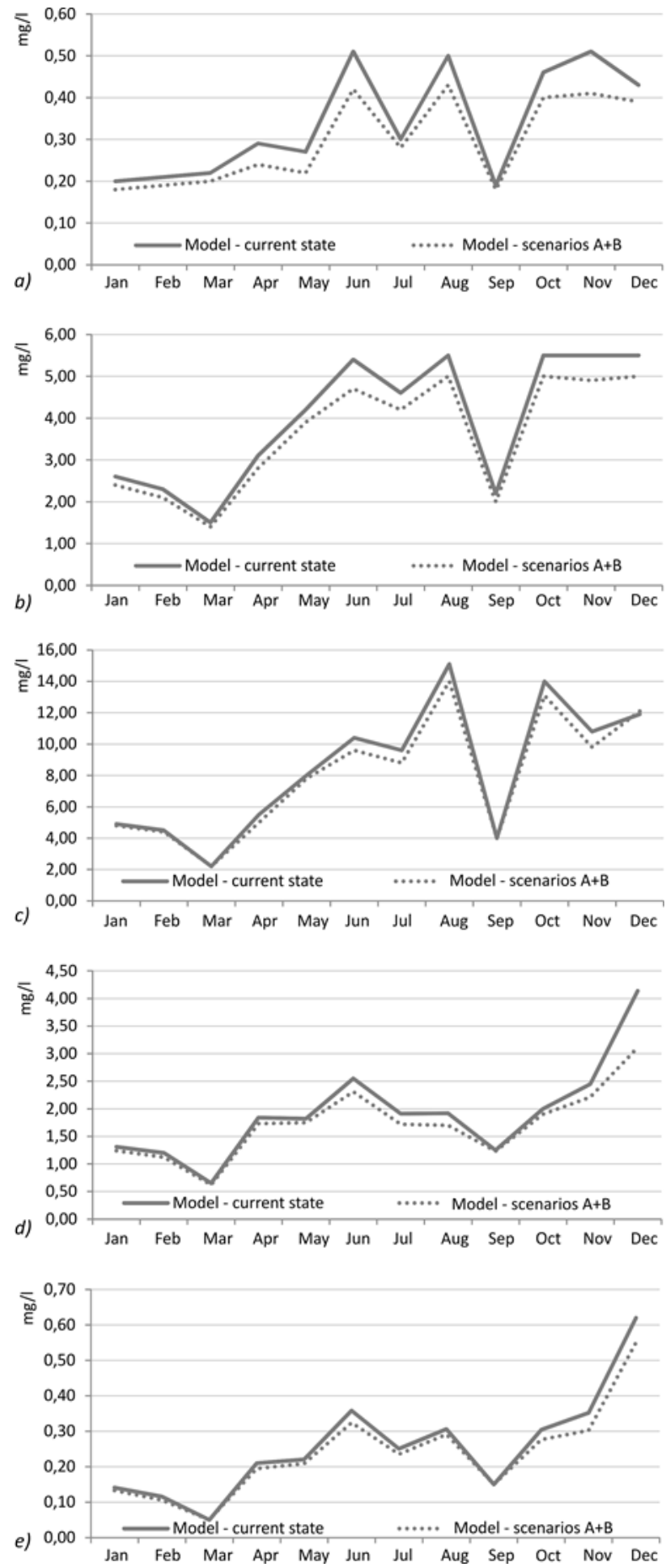

Fig. 7. Changes of seasonal variations of water quality after the application of simulated measures for selected indicators: a) N$\mathrm{NH}_{4}^{+}$, b) $\mathrm{BOD}_{5}$, c) $\left.\mathrm{COD}, \mathrm{d}\right) \mathrm{N}-\mathrm{NO}_{3}$ and e) $\mathrm{P}_{\text {total }}$.

The balance between the required level of detail for input data and sufficient accuracy of the output is one of the key problems reported in a number of reports studying different water quality and non-point pollution models (Borah and Bera, 2003). The most common issue for complex models is the large sets of required input data and parameters that are not regularly observed and are difficult to be derived correctly. This problem was reported for the SWAT and HSPF models, applied either on small catchments (Engelmann et al., 2002; Saleh and Du, 2004) or in large basins (Santhi et al., 2001).

The MIKE Basin model seems to offer a reasonable balance between data requirements and accuracy of the results obtained. It can describe the most important key factors of water quality and screen the catchment for identifying the most important problems. Such approach is mostly beneficial in catchments of macro- and meso-scales where the lack of accurate data is often a limiting condition for a detailed assessment.

The conceptualization of the MIKE Basin model results in some simplifications that must be taken into consideration when analysing results in spatial detail. One simplification is the inability of the Water Quality module to describe the yearly variability of decay coefficients. The decay coefficient can be extremely variable in time and space (Behrendt et al., 1995). The model, however, uses only one average value of the decay coefficient per water quality model which cannot reflect the seasonal changes.

The correct analysis and interpretation of the model results are also affected by the way the model handles the combination of specific pollution loads within stream water quality. The specific pollution load is added only at the sub-basin nodes. The specific pollution loads affect the water quality continuously along the assessed stream segments; however, the model conceptualization makes these changes locally specific and abrupt.

The application of the model to the Olšava River Basin points to several typical problems related with water quality modelling and water management in rural catchments, which can affect the level of assessment uncertainty.

An imbalance between data availability and model requirements is one of the key issues for the correct setup of a water quality model, especially in the often-missing or incomplete data on water usage. The model requires the input of discharges and concentrations of pollution emissions in the form of a time series. This requirement is easily fulfilled at large municipal and industrial sources (Langhammer, 2004). However, the discharges and concentrations of pollutants from local point sources are usually not included in the common databases, are reported only by yearly average values, or in some cases, they are not monitored at all. The preparation of the input dataset is thus based partially on indirect calculations and averaging, and is burdened with uncertainty.

Another source of uncertainty is the sparse network of discharge and water quality monitoring on small streams, as they are necessary as data sources for boundary conditions and for model calibration. The monitoring networks in small basins are usually sparse, time series are short and the monitoring interval is infrequent (Beránková et al. 2010). The missing quantitative information must be taken from the most similar or the nearest profile. In rare cases, the quantitative values had to be balanced using the upper and lower profiles.

The low frequency of water quality monitoring in rural basins can also negatively affect the reliability of assessment in parameters reflecting the non-point pollution. The monthly sampling interval, which is standard for regular monitoring networks, covers mostly low and average discharges (e.g. Kulasova et al., 2012). When the nutrients are washed out with water erosion during high rainfall-runoff events (Kliment et al., 2007, pollution loads may be underestimated. Nevertheless, the 
storm runoff from areas with extensive dairy or beef farming is burdened by intensive pollution from farmyard runoff, which has been proven to be a source of high levels of contamination, but usually is not included in any pollution estimates (Edwards et al., 2008). The underestimation of pollution loads at the level of basic monitoring as well as potential pollution sources can distort the whole picture of the actual pollution levels and result in incorrect calibration of models and misinterpretation of modelling results.

For practical applications of theoretical results of a modelling study, it is important to take into consideration the limited effect that the adopted water quality management measures have in rural basins, due to a variety of reasons. One of most critical problems is the large lag time between adoption of new management practices and water quality response. Experience from various environments indicates that the lag time between adoption of measures and the first measurable improvement in water quality in a small catchment can be higher than 10 years for nitrate pollution, and higher than 20 years for phosphorus (Meals et al., 2010).

The causes of such an elevated lag time are manifold, but they primarily depend on the intensity of previous agricultural practices and physiographic properties of the catchment. The key problems are the legacy sources of nutrients and the long residence time of pollution in groundwater systems (Sharpley et al., 2013). Analyses using isotope tracers in various model basins (e.g. Böhlke and Denver, 1995; Tomer and Burkart, 2003) proved the long residence time of nitrogen pollution in groundwater systems in environments previously exposed to intense fertilisation. This can result in stable elevated levels of pollution in rural catchments, despite changes in management (Langhammer, 2010). This principle can apply also to the Olšava Basin as it has been, as other rural basins in the Czech Republic, exposed to almost unrestricted fertilisation in the time of extensive agricultural production in 1970-80s (Langhammer and Kliment, 2009). In the Olšava Basin, the changes in agriculture were significant. Since 1990, 10.2\% of arable land in headwater areas was converted into permanent grassland, which was followed by a sharp decrease of the use of fertilizers, due to economic reasons (Langhammer and Kliment, 2009). The minimal response in the change of nutrient loads in recipients may originate in persistent leaching of nutrients from the legacy loads and may hinder positive changes in the future.

Another aspect affecting the real efficiency of calculated pollution decline is the imbalance in measures focused on depollution in phosphorus and nitrogen from agricultural sources (Carpenter et al., 1998; Sharpley et al., 1994). The application of the EU Nitrate directive (EC, 1991) often leads to the preference of measures eliminating nitrate pollution, with a lack of adequate measures focused on the elimination of phosphorus in rivers. Systematic care on phosphorus pollution is essential for water quality improvements and reduction of extensive eutrophication processes (Deasy et al., 2010).

Other problems related to the pollution of small basins are the mismanagement of facilities, lack of systematic approach, and little enforcement of environmental legislation. The key sources of extensive pollution in small streams are local pollution sources that are not connected to the sewage network, and mismanaged wastewater treatment facilities at small municipalities (Langhammer and Rödlová, 2013). These sources have a significant effect on resulting water quality, but they are difficult to measure or estimate, as they are unlisted in official databases (Meals et al., 2010).

The lag time between change in management practices and water quality improvement should be considered as an im- portant phenomenon in the evaluation of success of adopted measures in rural basins. In the case of the Olšava River Basin, the modelling study indicates that despite the abovementioned discussed factors that are slowing improvement of water quality, the basin has the potential to recover from intense past pollution and achieve the requirements of EU environmental legislation. However, the water management of the basin should pay attention to all potential factors that may potentially slow pollution recovery and properly set up a water quality monitoring system that is able to recognize the changes in reaction to adopted measures.

\section{CONCLUSIONS}

The MIKE Basin model used in this study was tested for practical applicability for the screening of rural catchments and for modelling the efficiency of proposed scenarios for the reduction of water pollution. The model tested the efficacy of measures designed to decrease water pollution by changes at point and non-point pollution sources.

The model was applied in the Olšava River Basin, Czech Republic, representing a typical rural region with a heterogeneous mixture of pollution sources, variable topography and land use, limited data on pollution sources, and a relatively sparse network of regular water quality monitoring data. The data from official sources were completed by the data from the author's long-term monitoring of water quality in the basin to check the model results and reliability.

The study indicated that this tool could be used successfully to build up and calibrate a functional complex water quality model, even with the limited amount of data typically available in rural basins. This limited availability of data is important for practical applicability of the model. The water managers usually build the models using standard data sources provided by the water management authorities. These standard data sources are limited in the peripheral regions.

The scenarios of the pollution reduction measures were based on the implementation of wastewater treatment at small untreated municipal sources, application of tertiary treatment at large point sources, and grassing of arable land at high risk of soil erosion. The simulation results proved that the measures proposed for reduction of water pollution with a view of their practical applicability can lead to fulfilment of the limits required by the Czech and EU legislation.

The positive effect of the proposed measures, indicated by simulations, can be less intense in practice due to several factors, typical for water quality management in rural basins. First, in small rural basins, there is a frequent lack of regular and systematic monitoring, and thus the design of simulations and proposed measures can be based on inappropriate values. Second, the depollution measures in rural basins are frequently focused on elimination of nitrogen and disregard phosphorus pollution. However, for efficiency of measures, both of the key nutrients should be appropriately treated. Last, but not least, the water management in small agricultural basins is often inefficient due to the poor state or mismanagement of wastewater treatment facilities and insufficient enforcement of the environmental legislation.

Acknowledgement. The research presented in this paper was supported by Charles University in Prague Research Center UNCE 204003/2012, and Research Program PRVOUK P43 with the support of grant project GAČR P209/12/0997. 


\section{REFERENCES}

Arnold, J.G., Fohrer, N., 2005. SWAT2000: Current capabilities and research opportunities in applied watershed modelling. Hydrol. Process., 19, 563-572.

Beránková, T., Vogel, R.M., Fiala, D., Rosendorf, P., 2010. Estimation of phosphorus loads with sparse data for agricultural watersheds in the Czech Republic. Hydrological Sciences Journal, 55, 1417-1426.

Beven, K., 2000. On the future of distributed modelling in hydrology. Hydrol. Process., 14, 3183-3184.

Borah, D.K., Bera, M., 2003. Watershed-scale hydrologic and non-point-source pollution models: Review of mathematical bases. Transactions of the ASAE 46, 1553-1566.

Böhlke, J.K., Denver, J.M., 1995. Combined Use of Groundwater Dating, Chemical, and Isotopic Analyses to Resolve the History and Fate of Nitrate Contamination in Two Agricultural Watersheds, Atlantic Coastal Plain, Maryland. Water Resour. Res., 31, 2319-2339.

Brown, L.C., Barnwell, T.O., 1987. The enhanced stream water quality models QUAL2E and QUAL2E-UNCAS: documentation and user manual. US Environmental Protection Agency. Office of Research and Development. Environmental Research Laboratory, Athens.

Buchanan, B., Easton, Z.M., Schneider, R., Walter, M.T., 2011. Incorporating Variable Source Area Hydrology into a Spatially Distributed Direct Runoff Model1. JAWRA Journal of the American Water Resources Association.

Carpenter, S.R., Caraco, N.F., Correll, D.L., Howarth, R.W., Sharpley, A.N., \& Smith, V.H., 1998. Non-point pollution of surface waters with phosphorus and nitrogen. Ecological applications, 8, 3, 559-568.

Chapra, S., Pelletier, G., Tao, H., 2006. QUAL2K: A modelling framework for simulating river and stream water quality, Version 2.04. Documentation and User's Manual. Civil and Environmental Engineering Department, Tufts University, Medford, MA, USA.

CSO, 2012. Czech Statistical Office - Public Database.

Damaška, J., Jurča, V., 1995. Extended sources of water contamination. Vodni Hospodarstvi, 45, 173-176.

Deasy, C., Quinton, J.N., Silgram, M., Bailey, A.P., Jackson, B., Stevens, C.J., 2010. Contributing understanding of mitigation options for phosphorus and sediment to a review of the efficacy of contemporary agricultural stewardship measures. Agr. Syst., 103, 2, 105-109.

DHI, 2008. MIKE Basin 2008. User's Guide. DHI, Horsholm.

Easton, Z.M., Fuka, D.R., Walter, M.T., Cowan, D.M., Schneiderman, E.M., Steenhuis, T.S., 2008. Re-conceptualizing the soil and water assessment tool (SWAT) model to predict runoff from variable source areas. J. Hydrol., 348, 279-291.

EC, 1991. Council Directive 91/676/EEC of 12 December 1991 concerning the protection of waters against pollution caused by nitrates from agricultural sources. (OJL375, 31.12.91, pl) European Communities, Brussels.

EC, 2000. Directive 2000/60/EC of the European Parliament and of the Council of 23 October 2000 establishing a framework for Community action in the field of water policy. Official Journal of the European Communities L327, 173.

Edwards, A.C., Kay, D., McDonald, A.T., Francis, C., Watkins, J., Wilkinson, J.R., Wyer, M.D., 2008. Farmyards, an overlooked source for highly contaminated runoff. J. Envrion. Manage., 87, 4, 551-559.

EEA, 2009. CORINE Landcover database.
EEC, 1991. Council Directive 91/676/EEC of 12 December 1991 concerning the protection of waters against pollution caused by nitrates from agricultural sources. Official Journal of the European Communities, 1991, 1-8.

Engelmann, C.J.K., Ward, A.D., Christy, A.D., Bair, E.S., 2002. Application of the BASINS Database and NPSM Model on a Small Ohio Watershed. Journal of the Astronomical Society of Western Australia, 38, 289-300.

EPA, U.S., 2000. Hydrological Simulation Program FORTRAN, User's Manual. Ver. 12. U.S. EPA, National Exposure Research Laboratory, Athens, GA.

EPA, U.S., 2001. Better Assessment Science Integrating Point and Non-point Sources User's Manual. Version 3.0. U.S. Environmental Protection Agency, Washington, D.C.

Havn, K., Madsen, M.N., Drge, J., Singh, V.P., 1995. MIKE 11-a generalized river modelling package. Computer models of watershed hydrology, 733-782.

Højberg, A.L., Refsgaard, J.C., Van Geer, F., Jørgensen, L.F., Zsuffa, I., 2007. Use of models to support the monitoring requirements in the water framework directive. Water Resour. Manag., 21, 1649-1672.

IPR, 2010. Integrated Pollution Register. Ministry of the Environment of the Czech Republic.

Jha, M.K., Gupta, A.D., 2003. Application of Mike Basin for water management strategies in a watershed. Water International, 28, 27-35.

Kliment, Z., Langhammer, J., Kadlec, J., Goudie, A., Kalvoda, J., 2007. The suspended load and soil erosion processes in mesoscale catchment areas. In: Goudie, A.S., Kalvoda, J. (Eds.): Geomorhoplogical Variations. P3K, Prague, 221252.

Kulasova, A., Smith, P.J., Beven, K.J., Blazkova, S.D., Hlavacek, J., 2012. A method of computing uncertain nitrogen and phosphorus loads in a small stream from an agricultural catchment using continuous monitoring data. J. Hydrol., 458, 1-8.

Langhammer, J., 2004. Modelling the structural changes of water quality in the Elbe river basin. Ekologia Bratislava, $23,157-169$.

Langhammer, J., 2010. Water quality changes in the Elbe River basin, Czech Republic, in the context of the post-socialist economic transition. GeoJournal, 75, 185-198.

Langhammer, J., Kliment, Z., 2009. Water quality changes in selected rural catchments in the Czech Republic. Ekologia Bratislava, 28, 312-332.

Langhammer, J., Rödlová, S., 2013. Changes in water quality in agricultural catchments after deployment of wastewater treatment plant. Environmental monitoring and assessment, $1-17$.

Maillard, P., Santos, N.A.P.A., 2008. A spatial-statistical approach for modeling the effect of non-point source pollution on different water quality parameters in the Velhas river watershed-Brazil. J. Environ. Manage., 86, 158-170.

Marsili-Libelli, S., Giusti, E., 2008. Water quality modelling for small river basins. Environmental Modelling \& Software 23, 451-463.

Meals, D.W., Dressing, S.A., Davenport, T.E., 2010. Lag time in water quality response to best management practices: A review. J. Environ. Qual., 39, 1, 85-96.

Nash, J., Sutcliffe, J.V., 1970. River flow forecasting through conceptual models part I-A discussion of principles. J. Hydrol., 10, 3, 282-290.

Nelson, E.J., Dellman, P.N., Ruiz, C.E., Manwaring, C.T., 2002. Watershed Modeling System Hydrological Simulation 
Program; Watershed Model User Documentation and Tutorial.

Nesmerrák, I., 2009. On the compensation of values below the detection limit in chemical analysis and monitoring of water quality status: the effect of substitution of values below the detection limit by the half of the quantification limit to the statistical characteristics of sets of values. Výzkumný ústav vodohospodářský T.G. Masaryka, Prague. (In Czech.)

Paliwal, R., Sharma, P., Kansal, A., 2007. Water quality modelling of the river Yamuna (India) using QUAL2E-UNCAS. J. Envrion. Manage., 83, 131-144.

Pekarova, P., Miklanek, P., Roncak, P., Adamkova, J., Chriastel, R., Metelkova, M., Pekar, J., 2004. Identification and assessment of long-term trends of surface water quality determinands in Slovakia for implementation of the EU WfD. J. Hydrol. Hydromech., 52, 317-328.

Psotová, H., 2008. The concept and strategy for the nature protection in Zlin Region, except protected areas. (mimo CHKO). In: Ochrana Př́rody a Krajiny Ve Zlínském Kraji. Veronica, Brno, 12-15. (In Czech.)

Ritter, W.F., Shirmohammadi, A., 2010. Agricultural Nonpoint Source Pollution. Watershed Management and Hydrology, CRC Press, US, p. 352.

Rosendorf, P., Prchalová, H., 1999. Elimination of non-point pollution of surface and subsurface waters. (Report for 1998) (in Czech.)

Saleh, A., Du, B., 2004. Evaluation of SWAT and HSPF within BASINS program for the Upper North Bosque River watershed in central Texas. Transactions of the ASAE 47, 10391049.

Salvetti, R., Acutis, M., Azzellino, A., Carpani, M., Giupponi, C., Parati, P., Vale, M., Vismara, R., 2008. Modelling the point and non-point nitrogen loads to the Venice Lagoon (Italy): the application of water quality models to the DeseZero basin. Desalination, 226, 81-88.

Santhi, C., Arnold, J.G., Williams, J.R., Dugas, W.A., Srinivasan, R., Hauck, L.M., 2001. Validation of the SWAT model on a large river basin with point and non-point sources. Journal of the American Water Resources Association, 37, 1169-1188.

Shanahan, P., Henze, M., Koncsos, L., Rauch, W., Reichert, P., Somlyody, L., Vanrolleghem, P., 1998. River water quality modelling: II. Problems of the art. Water Sci. Technol., 38, 245-252.

Sharpley, A.N., Chapra, S.C., Wedepohl, R., Sims, J.T., Daniel, T.C., Reddy, K.R., 1994. Managing agricultural phosphorus for protection of surface waters: Issues and options. J. Environ. Qual., 23, 3, 437-451.

Sharpley, A., Jarvie, H.P., Buda, A., May, L., Spears, B., Kleinman, P., 2013. Phosphorus legacy: Overcoming the effects of past management practices to mitigate future water quality impairment. J. Environ. Qual., 42, 5, 1308-1326.

Synáčková, M., 1996. Water quality. ČVUT Publishing House. Prague. p. 208. (In Czech.)

Tachecí, P., 2009. Methodology for assessment of the impact of considered water quality improvement measures using MIKE-BASIN model. DHI, Prague. p. 63. (In Czech.)

Tomer, M.D., Burkart, M.R., 2003. Long-term effects of nitrogen fertilizer use on ground water nitrate in two small watersheds. J. Environ. Qual., 32, 6, 2158-2171.

Wang, C., Wang, Y., Wang, P., 2006. Water quality modeling and pollution control for the Eastern route of South to North water transfer project in China. Journal of Hydrodynamics $18,253-261$.

Withers, P.J.A, et al., 2007. The impact of pasture improvement on phosphorus concentration in soils and streams in an upland catchment in Northern England. Agriculture, Ecosystems and Environment, 122, 220-232.

WRI, 2010. DIBAVOD. Water Management Geodatabase. VUV TGM, Prague.

Received 2 January 2013

Accepted 22 October 2013 